\title{
Assessment of yield and quality of double-spore champignon mushrooms
}

\author{
Ekaterina G. Alexandrova*, Vladimir A. Milyutkin, and Oksana A. Blinova
}

Department of Production Technology and Expertise of Products from Plant Materials, Samara State Agrarian University, 446442 Samara, Russia

\begin{abstract}
The article presents the results of experimental data characterizing the yield and quality of double-spore champignon mushrooms obtained by their cultivation on the substrate with the use of organic additives of plant and animal origin - waste of food and processing industries: sunflower husks, meat and buckwheat meal and coarse grains. The yield of mushrooms is estimated by periods of substrate preparation (winter and summer) and fruit-bearing waves. Higher yield of mushrooms of mushrooms of double-spore champignon was obtained on the substrate prepared in summer for two waves of fruiting. Assessment of the quality of mushrooms involved studying the content of protein, fiber, fat and ash elements (potassium, phosphorus, calcium, sodium and magnesium). The results show that sunflower husk and meat and bone meal are the best organic additives that not only increase the yield of mushrooms, but also their quality. The study shows that the quality of mushrooms obtained in the second wave is significantly higher than the quality of mushrooms obtained in the previous wave. Positive is the fact that the use of organic waste in industrial mushroom production contributes to the efficient management of, as a rule, little used by-products of food and processing industries.
\end{abstract}

\section{Introduction}

Cultivation of cultivated mushrooms attracts special attention of producers of agricultural products, because on the one hand it allows to receive additional income, and on the other hand - to utilize by-products of agriculture $[1,2]$.

Industrial production of mushrooms in Russia started relatively recently, however, the rate of increase in production potential is impressive.

Studies have shown that the availability of compost raw materials, the use of intensive technologies aimed at reducing the time of substrate growth and distillation of fruit bodies are the main reserves for growth in the production of mushroom products $[3,4]$.

In addition, the food industry processing agricultural raw materials discharges waste containing organic (free) matter into the environment [5-7].

Taking into account the environmental aspect and high raw material value of these wastes, the issues of development of methods for their full utilization in order to further useful use are very relevant.

The purpose of this study is to study the influence of the type and method of application of organic additives of plant and animal origin on the yield and quality of mushrooms of mushrooms of double-spore.

\section{Materials and methods}

Research on the influence of organic additives and methods of their introduction in the process of cultivation on the chemical composition of mushrooms were conducted in the training laboratories of the Department of "Technology of production and examination of products from plant raw materials" of the Faculty of Technology of FSBEI HEI Samara State Automobile University.

The factor model of experiments is presented in Figure 1.

The main parameters used in the experiments are systematized in Table 1.

\footnotetext{
*Corresponding author: fegtgf@mail.ru
} 


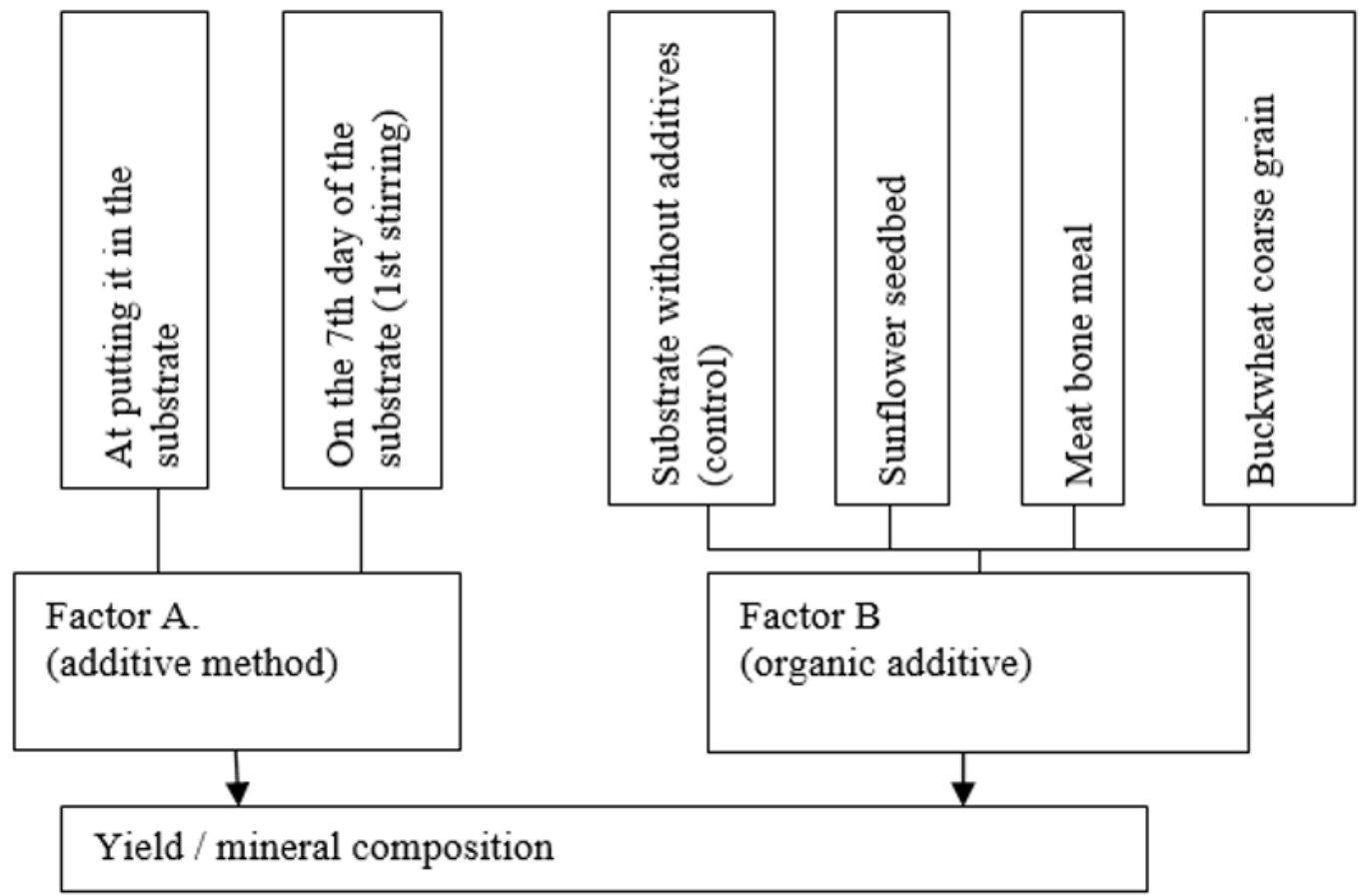

Fig. 1. Scheme of experience in studying the influence of the type and method of organic additives used in the cultivation of doublespore champignon on the yield and mineral composition.

Table 1. Conditions of testing.

\begin{tabular}{|l|l|}
\hline \multicolumn{1}{|c|}{ Index } & \multicolumn{1}{c|}{ Description } \\
\hline Repetition of experiments & Four times \\
\hline Mycelium application rate & $5 \%$ of the mass of the raw substrate \\
\hline Substrate height & $15 \mathrm{~cm}$ \\
\hline $\begin{array}{l}\text { A strain of double-spore champignon (Agaricus } \\
\text { bisporus) }\end{array}$ & A-15 (white) [8] \\
\hline Substrate manufacturer & OOO Orix \\
\hline Preparation time of substrate & $\begin{array}{l}1 . \text { Winter period (February-March); } \\
2 . \text { summer period (August-September). }\end{array}$ \\
\hline $\begin{array}{l}\text { Composition of synthetic substrate } \\
\text { Nitrogen content in substrate on dry matter: }\end{array}$ & $\begin{array}{l}50 \% \text { wheat straw, 50\% poultry manure, gypsum at the rate of } \\
\text { - organic; - ammoniacal }\end{array}$ \\
\hline Active acidity $(\mathrm{pH})$ & 2.1 to $2.4 \%$, no more than $0.02 \%$ \\
\hline
\end{tabular}

\section{Results}

It has been experimentally established that the duration and yield of gypsum mushrooms depends largely on the time of preparation of the synthetic substrate [9]: one wave of fruiting was observed on the substrate prepared in winter, while the substrate prepared in summer allowed to receive two waves.

The use of organic plant or animal additives in all applications increased the collection of mushrooms for the first wave of fruiting (Table 2).

When applying organic additives to the substrate, the greatest effect was noted on the variants with buckwheat coarse grains and meat and bone meal, where the yield of gypsum mushrooms for the first wave of fruiting was 8.20 and $8.87 \mathrm{~kg} / \mathrm{m}^{2}$, respectively. These additives showed a good result when applied to the substrate on day 7 .

On the synthetic substrate prepared in summer without organic additives, the yield of mushrooms in total for two waves was $7.71 \mathrm{~kg} / \mathrm{m}^{2}$ (Table 3 ).

When buckwheat coarse grains were added to the substrate when it was laid on shelves, the yield of mushrooms for the first wave of fruiting practically corresponded to the level of yield from the substrate prepared in winter. The largest collection of mushrooms from the substrate cooked in summer was noted on the variants of experience with the use of meat and bone meal.

Thus, the highest collection of mushrooms during their cultivation on the substrate cooked in summer can be stimulated by the use of meat and bone meal as an 
organic additive and its application during the first mixing of the substrate.

Based on the results of the analysis of the influence of the type and method of additive application on the chemical composition of the double-spore champignon, the following conclusions were drawn.

The content of raw protein in the yield of mushrooms grown without organic additives was $28.82 \%$ on average per dry matter (Table 4).

Table 2. Yield of mushrooms of double-spore champignon on a synthetic substrate prepared in winter, $\mathrm{kg} / \mathrm{m}^{2}$.

\begin{tabular}{|l|c|c|}
\hline \multirow{2}{*}{ Type of organic additive } & \multicolumn{2}{|c|}{ Timing and application methods } \\
\cline { 2 - 3 } & in the substrate & $\begin{array}{c}\text { on day seven of the } \\
\text { substrate }\end{array}$ \\
\hline No additives (control) & 5.77 & - \\
\hline Sunflower seedbed & 5.93 & 7.87 \\
\hline Meat bone meal & 8.87 & 9.20 \\
\hline The buckwheat coarse & 8.20 & 9.93 \\
\hline
\end{tabular}

Table 3. Yield of mushrooms of double-spore mushrooms on a synthetic substrate prepared in summer, $\mathrm{kg} / \mathrm{m}^{2}$.

\begin{tabular}{|c|c|c|c|}
\hline \multirow{2}{*}{$\begin{array}{c}\text { Type of organic } \\
\text { additive }\end{array}$} & \multirow{2}{*}{$\begin{array}{l}\text { The waves of } \\
\text { fruiting }\end{array}$} & \multicolumn{2}{|c|}{ Timing and application methods } \\
\hline & & in the substrate & $\begin{array}{c}\text { on day } 7 \text { to the } \\
\text { substrate }\end{array}$ \\
\hline \multirow{3}{*}{ No additives (control) } & 1 wave & 5.36 & - \\
\hline & 2 wave & 2.35 & - \\
\hline & Total & 7.71 & - \\
\hline \multirow{3}{*}{ Sunflower seedbed } & 1 wave & 5.40 & 9.69 \\
\hline & 2 wave & 2.17 & 3.57 \\
\hline & Total & 7.57 & 13.26 \\
\hline \multirow{3}{*}{ Meat bone meal } & 1 wave & 8.95 & 9.59 \\
\hline & 2 wave & 3.57 & 3.90 \\
\hline & Total & 12.52 & 13.49 \\
\hline \multirow{3}{*}{$\begin{array}{l}\text { The buckwheat } \\
\text { coarse }\end{array}$} & 1 wave & 8.20 & 9.23 \\
\hline & 2 wave & 4.02 & 3.77 \\
\hline & Total & 12.22 & 13.00 \\
\hline
\end{tabular}

Table 4. Chemical composition of mushrooms grown on a synthetic substrate prepared in winter, $\%$ on a.d.m..

\begin{tabular}{|l|l|c|c|c|c|}
\hline \multirow{2}{*}{$\begin{array}{c}\text { Type of organic } \\
\text { additive }\end{array}$} & \multicolumn{2}{|c|}{$\begin{array}{c}\text { Timing and } \\
\text { application } \\
\text { methods }\end{array}$} & \multicolumn{3}{|c|}{$\begin{array}{c}\text { Chemical composition of champignon fruit } \\
\text { bodies }\end{array}$} \\
\cline { 3 - 6 } & $\begin{array}{c}\text { nitroge } \\
\mathrm{n}\end{array}$ & protein & fibre & fat \\
\hline No additives & - & 4.61 & 28.82 & 7.33 & 1.63 \\
\hline \multirow{2}{*}{$\begin{array}{l}\text { Sunflower } \\
\text { seedbed }\end{array}$} & $\begin{array}{l}\text { When putting in } \\
\text { the substrate }\end{array}$ & 4.85 & 30.33 & 8.50 & 1.65 \\
\cline { 2 - 6 } & $\begin{array}{l}\text { On the 7th day of } \\
\text { the substrate. }\end{array}$ & 4.90 & 30.62 & 8.15 & 1.62 \\
\hline \multirow{2}{*}{ Meat bone meal } & $\begin{array}{l}\text { When putting in } \\
\text { the substrate }\end{array}$ & 4.83 & 30.19 & 7.87 & 1.81 \\
\cline { 2 - 6 } & $\begin{array}{l}\text { On the 7th day of } \\
\text { the substrate. }\end{array}$ & 4.85 & 30.29 & 7.68 & 1.55 \\
\hline \multirow{2}{*}{$\begin{array}{l}\text { The buckwheat } \\
\text { coarse }\end{array}$} & $\begin{array}{l}\text { When putting in } \\
\text { the substrate }\end{array}$ & 4.69 & 29.31 & 7.69 & 1.75 \\
\cline { 2 - 6 } & $\begin{array}{l}\text { On the 7th day of } \\
\text { the substrate. }\end{array}$ & 4.87 & 30.45 & 7.97 & 1.61 \\
\hline
\end{tabular}

The use of organic additives of plant and animal origin increased the amount of raw protein in mushrooms [10-12].

The highest content of raw protein in mushrooms was observed when sunflower husks and buckwheat coarse grains were added to the substrate for the first mixing of the substrate.
The lowest fibre content is noted in mushrooms grown on the substrate without the use of organic additives, and the highest - in variants with the addition of husk as an organic additive of sunflower husk.

The highest content of raw fat in the dry matter of mushrooms fruit bodies is noted when growing them on the substrate with the use of meat and buckwheat meal and buckwheat cereals when laying. 
For all methods of sunflower husk application the content of raw fat in dry matter of mushrooms remains practically unchanged.

The content of protein, fiber and fat in mushrooms of double-spore mushrooms collected from the substrate cooked in summer is higher than in mushrooms from the substrate cooked in winter (Table 5).

The largest amount of raw protein was contained in the mushrooms of the first wave with the use of sunflower husk as an organic additive, especially when it was applied on the 7th day in the substrate, and was an average of $30.53 \%$ per dry matter. A sufficiently high raw protein content was observed in the dry matter of mushrooms derived from experimental variants using additives such as meat and buckwheat meal and buckwheat groats.

Analysis of the chemical composition of mushrooms grown in the second wave, showed that it exceeds the indicators (nitrogen, protein, fiber), noted in the first wave.

Organic additives of plant and animal origin, depending on the timing and method of their application, had an ambiguous effect on the content of minerals in the fruit bodies of mushrooms (Table 6).

Table 5. Chemical composition of mushrooms of double-spore champignon, grown on a synthetic substrate prepared in summer, $\%$ on a.d.m.

\begin{tabular}{|c|c|c|c|c|c|c|c|c|c|}
\hline \multirow{4}{*}{$\begin{array}{l}\text { Type of organic } \\
\text { additive }\end{array}$} & \multirow{4}{*}{$\begin{array}{l}\text { Timing and } \\
\text { application } \\
\text { methods }\end{array}$} & \multicolumn{8}{|c|}{ Chemical composition of champignon fruit bodies } \\
\hline & & \multicolumn{2}{|c|}{ nitrogen } & \multirow{2}{*}{\multicolumn{3}{|c|}{\begin{tabular}{c|c} 
protein & fil \\
fruiting wave
\end{tabular}}} & & \multicolumn{2}{|c|}{ fat } \\
\hline & & & & & & & & & \\
\hline & & 1 & 2 & 1 & 2 & 1 & 2 & 1 & 2 \\
\hline No additives & - & 4.74 & 4.78 & 29.58 & 29.86 & 7.20 & 7.26 & 1.65 & 1.60 \\
\hline \multirow{2}{*}{ Sunflower seedbed } & $\begin{array}{l}\text { When putting in } \\
\text { the substrate }\end{array}$ & 4.82 & 4.85 & 30.14 & 30.31 & 8.12 & 8.16 & 1.61 & 1.66 \\
\hline & $\begin{array}{l}\text { On the 7th day of } \\
\text { the substrate }\end{array}$ & 4.89 & 4.81 & 30.53 & 30.05 & 8.10 & 7.87 & 1.57 & 1.58 \\
\hline \multirow{2}{*}{ Meat bone meal } & $\begin{array}{l}\text { When putting in } \\
\text { the substrate }\end{array}$ & 4.82 & 4.84 & 30.13 & 30.22 & 8.02 & 7.25 & 1.73 & 1.81 \\
\hline & $\begin{array}{l}\text { On the } 7 \text { th day of } \\
\text { the substrate }\end{array}$ & 4.85 & 4.90 & 30.32 & 30.62 & 8.30 & 8.19 & 1.82 & 1.54 \\
\hline \multirow{2}{*}{ The buckwheat coarse } & $\begin{array}{l}\text { When putting in } \\
\text { the substrate }\end{array}$ & 4.66 & 4.93 & 29.10 & 30.78 & 8.33 & 7.80 & 1.62 & 1.80 \\
\hline & $\begin{array}{l}\text { On the } 7 \text { th day of } \\
\text { the substrate }\end{array}$ & 4.85 & 4.83 & 30.32 & 30.19 & 8.50 & 7.48 & 1.67 & 1.55 \\
\hline
\end{tabular}

Table 6. Mineral content of mushrooms grown on a synthetic substrate prepared in winter, $\%$ on a.d.m.

\begin{tabular}{|c|c|c|c|c|c|c|c|}
\hline \multirow{2}{*}{$\begin{array}{ll}\text { Type } & \text { of } \\
\text { organic } & \\
\text { additive } & \end{array}$} & \multirow{2}{*}{$\begin{array}{l}\text { Timing and } \\
\text { application } \\
\text { methods }\end{array}$} & \multicolumn{6}{|c|}{ Mineral composition of champignon fruit bodies } \\
\hline & & Ash & $\begin{array}{l}\text { Potas } \\
\text { sium }\end{array}$ & $\begin{array}{l}\text { Phosph } \\
\text { orus }\end{array}$ & Calcium & $\begin{array}{l}\text { Magnes } \\
\text { ium }\end{array}$ & Sodium \\
\hline No additives & - & 5.82 & 3.29 & 0.79 & 0.051 & 0.13 & 0.069 \\
\hline \multirow{2}{*}{$\begin{array}{l}\text { Sunflower } \\
\text { seedbed }\end{array}$} & $\begin{array}{l}\text { When } \\
\text { putting in } \\
\text { the substrate }\end{array}$ & 6.20 & 3.57 & 0.73 & 0.054 & 0.14 & 0.060 \\
\hline & $\begin{array}{l}\text { On the } 7 \text { th } \\
\text { day of the } \\
\text { substrate }\end{array}$ & 6.04 & 3.60 & 0.70 & 0.054 & 0.11 & 0.073 \\
\hline \multirow{2}{*}{$\begin{array}{l}\text { Meat bone } \\
\text { meal }\end{array}$} & $\begin{array}{l}\text { When } \\
\text { putting in } \\
\text { the substrate }\end{array}$ & 6.14 & 3.55 & 0.79 & 0.048 & 0.10 & 0.063 \\
\hline & $\begin{array}{l}\text { On the } 7 \text { th } \\
\text { day of the } \\
\text { substrate }\end{array}$ & 6.07 & 3.46 & 0.75 & 0.057 & 0.12 & 0.065 \\
\hline \multirow{2}{*}{$\begin{array}{l}\text { The } \\
\text { buckwheat } \\
\text { coarse }\end{array}$} & $\begin{array}{l}\text { When } \\
\text { putting in } \\
\text { the substrate }\end{array}$ & 6.01 & 3.36 & 0.79 & 0.052 & 0.13 & 0.069 \\
\hline & $\begin{array}{l}\text { On the } 7 \text { th } \\
\text { day of the } \\
\text { substrate }\end{array}$ & 5.91 & 3.45 & 0.71 & 0.057 & 0.10 & 0.077 \\
\hline
\end{tabular}


At introduction of organic additives of plant and animal origin in the substrate, the content of raw ash in the dry matter of fruit bodies increases in comparison with the result of the reference sample on the average from 0,09 to $0,38 \%$, potassium - from 0,07 to $0,31 \%$, the amount of phosphorus decreases, and the mass fraction of calcium, magnesium and sodium remains almost at the same level as without the use of additives. The largest amount of raw ash and potassium is found in mushrooms grown on a synthetic substrate, with the addition of sunflower husk as an organic additive [13, $14]$.

In mushrooms obtained on the substrate prepared in summer, the content of minerals was determined not only by the influence of the type of organic additive and the method of its application, but also largely depended on the wave of fruiting mushrooms gipsy (Table 7).

Table 7. Mineral content in mushrooms of double-spore mushrooms grown on a synthetic substrate prepared in summer, $\%$ on a.d.m.

\begin{tabular}{|c|c|c|c|c|c|c|c|c|}
\hline \multirow{2}{*}{$\begin{array}{l}\text { Type of } \\
\text { organic } \\
\text { additive }\end{array}$} & \multirow{2}{*}{$\begin{array}{l}\text { Timing and } \\
\text { application } \\
\text { methods }\end{array}$} & \multirow{2}{*}{$\begin{array}{l}\text { Wave of } \\
\text { fruiting }\end{array}$} & \multicolumn{6}{|c|}{ Mineral composition of champignon fruit bodies } \\
\hline & & & Ash & $\begin{array}{l}\text { Potass } \\
\text { ium }\end{array}$ & $\begin{array}{c}\text { Phosphor } \\
\text { us }\end{array}$ & $\begin{array}{c}\text { Calci } \\
\text { um }\end{array}$ & $\begin{array}{c}\text { Magnesi } \\
\text { um }\end{array}$ & Sodium \\
\hline \multirow{2}{*}{$\begin{array}{l}\text { No } \\
\text { additives }\end{array}$} & \multirow[t]{2}{*}{ 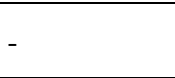 } & 1 wave & 5.6 & 3.34 & 0.72 & 0.051 & 0.12 & 0.061 \\
\hline & & 2 wave & 5.8 & 3.42 & 0.62 & 0.041 & 0.07 & 0.046 \\
\hline \multirow{4}{*}{$\begin{array}{l}\text { Sunflowe } \\
\mathrm{r} \text { seedbed }\end{array}$} & \multirow{2}{*}{$\begin{array}{l}\text { When } \\
\text { putting in } \\
\text { the substrate }\end{array}$} & 1 wave & 5.97 & 3.61 & 0.63 & 0.052 & 0.12 & 0.051 \\
\hline & & 2 wave & 5.95 & 3.57 & 0.65 & 0.041 & 0.07 & 0.048 \\
\hline & \multirow{2}{*}{$\begin{array}{l}\text { On the } 7 \text { th } \\
\text { day of the } \\
\text { substrate }\end{array}$} & 1 wave & 5.95 & 3.56 & 0.65 & 0.054 & 0.11 & 0.057 \\
\hline & & 2 wave & 5.88 & 3.56 & 0.65 & 0.043 & 0.06 & 0.046 \\
\hline \multirow{4}{*}{$\begin{array}{l}\text { Meat } \\
\text { bone } \\
\text { meal }\end{array}$} & \multirow{2}{*}{$\begin{array}{l}\text { When } \\
\text { putting in } \\
\text { the substrate }\end{array}$} & 1 wave & 6.14 & 3.55 & 0.67 & 0.057 & 0.10 & 0.063 \\
\hline & & 2 wave & 6.04 & 3.55 & 0.65 & 0.042 & 0.07 & 0.046 \\
\hline & \multirow{2}{*}{$\begin{array}{l}\text { On the } 7 \text { th } \\
\text { day of the } \\
\text { substrate }\end{array}$} & 1 wave & 5.89 & 3.44 & 0.65 & 0.060 & 0.13 & 0.063 \\
\hline & & 2 wave & 5.78 & 3.48 & 0.65 & 0.041 & 0.07 & 0.045 \\
\hline \multirow{4}{*}{$\begin{array}{l}\text { The } \\
\text { buckwhea } \\
\text { t coarse }\end{array}$} & \multirow{2}{*}{$\begin{array}{l}\text { When } \\
\text { putting in } \\
\text { the substrate }\end{array}$} & 1 wave & 6.00 & 3.35 & 0.64 & 0.042 & 0.13 & 0.062 \\
\hline & & 2 wave & 6.04 & 3.52 & 0.63 & 0.036 & 0.07 & 0.046 \\
\hline & \multirow{2}{*}{$\begin{array}{l}\text { On the } 7 \text { th } \\
\text { day of the } \\
\text { substrate }\end{array}$} & 1 wave & 6.20 & 3.46 & 0.66 & 0.057 & 0.09 & 0.064 \\
\hline & & 2 wave & 6.11 & 3.52 & 0.65 & 0.042 & 0.08 & 0.046 \\
\hline
\end{tabular}

It was also revealed that the dry matter of mushrooms of the first wave harvest, in comparison with mushrooms of the second wave, contains more raw ash, phosphorus, calcium, magnesium and sodium, but, at the same time, they have a lower content of potassium.

The highest content of raw ash in the dry matter of fruit bodies of champignon of double-spore first wave grown on the substrate prepared in summer is usually observed on the variants where meat and bone meal is used as an organic additive (when applying it when laying) or buckwheat coarse from buckwheat grain on the 7 th day in the substrate (1st mixing). The higher content of ash elements in mushrooms of the first and second wave of fruiting when using buckwheat meal and coarse grains is due to the fact that they contain more potassium, phosphorus, calcium, magnesium and sodium than in other organic additives.

\section{Discussion}

The carried out research allows to estimate the possibility of using organic additives as the main factors of increasing the yield and quality of cultivated mushrooms [15]. Cultivation of mushrooms on a synthetic substrate prepared in summer allows to receive two waves of harvest, and, accordingly, a larger volume of products. Also, the increase in yield provides the addition of meat and bone meal to the substrate. The introduction of organic additives into the substrate affects the quality of products [16]. Application of sunflower husk increases the amount of protein, fiber, fat and ash elements. Particular attention should be paid to the fact that the production of mushrooms of the highest quality was recorded in the conditions of the experience carried out on the substrate prepared in the summer period, in the second wave. The use of organic additives in the process of mushroom cultivation is of great industrial importance - on the one hand, there is a reduction in the load from agricultural producers and food production enterprises on waste disposal, and on the other hand, contributes to the growth of production and quality of mushroom products.

\section{Conclusion}

Sunflower seedbeds and meat and bone meal are environmentally friendly organic additives. Their use in mushroom growing as an additive to the substrate allows to enrich it with additional nutrients, which will have a positive impact on productivity and quality of products. 


\section{References}

1. W. Li-ning, G. Wei, W. Qiong-ying, Q. Ji-bin, Z. Jinxia, H. Chen-yang, J. of Integrative Agriculture 18(3), 580-589 (2019) doi.org/10.1016/S20953119(18)62126-4.

2. C. Pandin, R. Védie, T. Rousseau, D. Le Coq, S. Aymerich, R. Briandet, Biological Control 127, 3954 (2018) doi.org/10.1016/j.biocontrol.2018.08.022.

3. S. Ting-ting, C. Wei-ming, J. Qun-li, F. Wei-lin, F. Lijun, S. Ying-yue, F. Hao, T. Fang-fang, Scientia Horticulturae 174, 96-104 (2014) doi.org/10.1016/j.scienta.2014.05.012.

4. R. Altieri, A. Esposito, F. Parati, A. Lobianco, M. Pepi, Int. Biodeterioration \& Biodegradation 63(8), 993-997 doi.org/10.1016/j.ibiod.2009.06.008.

(2009)

5. J. D. W. Adams, L. E. Frostick, Bioresource Technology 99(5), 1097-1102 (2008) doi.org/10.1016/j.biortech.2007.02.019.

6. J.-M. Savoie, G. Mata, Mushroom Biotechnology Developments and Applications 69-91, (2016) doi.org/10.1016/B978-0-12-802794-3.00005-9.

7. F. Parati, R. Altieri, A. Esposito, A. Lobianco, M. Pepi, L. Montesi, T. Nair, Int. Biodeterioration \& Biodegradation 65, 1160-163 (2011) doi.org/10.1016/j.ibiod.2010.10.009.

8. M. V. A. Pontes, A. Patyshakuliyeva, H. Post, E. Jurak, K. Hildén, M. Altelaar, A. Heck, M. A. Kabel, R. P. de Vries, M. R. Mäkelä, Fungal Genetics and Biology 112, 12-20 (2018) doi.org/10.1016/j.fgb.2017.12.004.
9. J. T. Wang, Q. Wang, J. R. Han, Scientia Horticulturae 157, 84-89 (2013) doi.org/10.1016/j.scienta.2013.04.006.

10. P. Rzymski, M. Mleczek, M. Siwulski, A. Jasińska, A. Budka, P. Niedzielski, P. Kalač, M. Gąsecka, S. Budzyńska, J. of Food Composition and Analysis, 59 $170-178$ (2017) doi.org/10.1016/j.jfca.2017.02.011.

11. T. Maseko, D. L. Callahan, F. R. Dunshea, A. Doronila, S. D. Kolev, Ken Ng, Food Chemistry 141(4), 3681-3687 (2013) doi.org/10.1016/j.foodchem.2013.06.027.

12. O. Arce-Cervantes, M. Saucedo-García, H. Leal Lara, R. Ramírez-Carrillo, F. Cruz-Sosa, O. Loera, Scientia Horticulturae 192(31), 375-380 (2015) doi.org/10.1016/j.scienta.2015.06.030.

13. J. Vetter, Food Chemistry 50(3), 277-279 (1994) doi.org/10.1016/0308-8146(94)90132-5.

14. S. R. Koyyalamudi, Sang-Chul Jeong, S. Manavalan, B. Vysetti, G. Pang, J. of Food Composition and Analysis 31(1), 109-114 (2013) doi.org/10.1016/j.jfca.2013.03.007

15. M. M. Coello-Castillo, J. E. Sánchez, D. J. Royse, Bioresource Technology 100(19), 4488-4492 (2009) doi.org/10.1016/j.biortech.2008.10.061.

16. M. Ramos, N. Burgos, A. Barnard, G. Evans, J. Preece, M. Graz, A. C. Ruthes, A. Jiménez-Quero, A. Martínez-Abad, F. Vilaplana, Long Pham Ngoc, A. Brouwer, B. der Burg, M. C. Garrigós, A. Jiménez, Food Chemistry 292(15), 176-187 (2019) doi.org/10.1016/j.foodchem.2019.04.035. 